\title{
Dietary Assessment Methods in Military and Veteran Populations: A Scoping Review
}

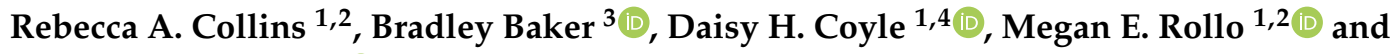 \\ Tracy L. Burrows 1,2 * (D) \\ 1 School of Health Sciences, Faculty of Health and Medicine, University of Newcastle, Callaghan 2308, \\ Australia; Rebecca.Collins10@uon.edu.au (R.A.C.); daisy.coyle@newcastle.edu.au (D.H.C.); \\ Megan.Rollo@newcastle.edu.au (M.E.R.) \\ 2 Priority Research Centre for Physical Activity and Nutrition, University of Newcastle, \\ Callaghan 2308, Australia \\ 3 Food and Nutrition, Land Division, Defence Science and Technology Group, Scottsdale 7260, Australia; \\ bradley.baker2@dst.defence.gov.au \\ 4 The George Institute for Global Health, University of New South Wales, Sydney 2042, Australia \\ * Correspondence: tracy.burrows@newcastle.edu.au; Tel.: +61-2-4921-5514
}

Received: 31 January 2020; Accepted: 10 March 2020; Published: 14 March 2020

\begin{abstract}
Optimal dietary intake is important for the health and physical performance of military personnel. For military veterans, the complex nature of transition into civilian life and sub-optimal dietary intake is a leading contributor to the increased burden of disease. A scoping review was undertaken to determine what is known about the assessment and reporting of dietary intakes within both military and veteran populations. In addition, this review determines if studies reporting on the dietary intake of military personnel or veterans include comparisons with dietary guidelines. Six databases were searched to identify papers published from the database inception to April 2019. Observational and intervention studies were searched to identify if they assessed and reported whole dietary intake data, reported data exclusively for a military or veteran population, and included only healthy populations. A total of 89 studies were included. The majority of studies used one dietary assessment method ( $n=76,85 \%$ ) with fewer using multiple methods $(n=13,15 \%)$. The most frequent methodology used was food frequency questionnaires (FFQ) $(n=40,45 \%)$ followed by 24 -hour recalls $(n=8,9 \%)$ and food records $(n=8,9 \%)$. The main dietary outcomes reported were macronutrients: carbohydrate, protein, fat, and alcohol $(n=66,74 \%)$ with total energy intake reported in $n=59(66 \%)$. Fifty four $(61 \%)$ studies reported a comparison with country-specific dietary guidelines and $14(16 \%)$ reported a comparison with the country-specific military guidelines. In conclusion, dietary intake in military settings is most commonly assessed via FFQs and 24-hour recalls. Dietary intake reporting is mainly focused around intakes of energy and macronutrients. Most studies compare against dietary guidelines, however, comparison to specific military dietary guidelines is minimal.
\end{abstract}

Keywords: scoping review; defense; military; diet; dietary assessment

\section{Introduction}

Optimal dietary intake is a crucial component of a military environment due to the high physical and mental demands placed on personnel [1-4]. Research to date has shown that the health, fitness and performance of military personnel is highly reliant on their nutritional status during training, and, therefore, their readiness to be deployed can be negatively affected by suboptimal nutrient intakes [2-5]. This is particularly relevant to service members in combat roles when on base preparing/training for field deployment [6]. To support their training, a focus on a healthy and optimal diet is essential for 
facilitating training adaptations, recovery, maintenance of health, and career progression within the military. Optimal nutrition is also important for reducing the risk of long-term health conditions such as obesity and cardiovascular disease $[7,8]$. This is not only pertinent to personnel actively serving in the military, but also to military veterans. As such, it is important to also consider the dietary intakes of the veteran community when assessing dietary factors that are linked to long-term health conditions.

The dietary requirements of active military personnel vary according to their occupation and work environment due to the differing physical and mental workloads across the vast range of roles and environments in which military personnel operate $[6,9,10]$. Considering this, in 2001, the United States of America (USA) military developed specific dietary guidelines, known as the Military Dietary Reference Intakes (MDRIs) [11,12]. The MDRIs incorporate aspects of the Dietary Guidelines [13] for Americans [1]. The guidelines also consider context specific factors such as the physical activity levels of military personnel and environmental elements, such as extremely hot desert environments [14]. Similarly, in Australia, the Australian Defence Force (ADF) also follows military specific dietary guidelines [15], which are based on the Australian Nutrient Reference Values (NRVs) [6]. Similar to in the USA, the guidelines take into account the various occupations and scenarios encountered by military personnel and their often increased macronutrients requirements. These are divided into five activity categories; those undertaking moderate to high physical activity and those in more sedentary roles [15]. The Nordic countries (Denmark, Finland, Iceland, Norway, Sweden) construct their military diets from the Nordic Nutrition Recommendations (NNR) [16], with the North Atlantic Treaty Organisation (NATO) ensuring military operations are meeting the mandatory food standards [16]. The standards include guidelines around the day-to-day nutrition provisions within the military environment [16].

The military environment is distinctive and some personnel may be required to shift their usual dietary intake between fresh foods to combat rations, which can be accompanied by variations in daily energy expenditure due to the impacts of training [17]. For example, the garrison environment, when compared to field work, often has a lessened physical impact on personnel with longer hours of recuperation periods and planned meal times [17,18]. Within the same garrison, the type of personnel must also be taken into account, for example, special forces personnel are likely to have much higher energy demands than personnel completing desk-based tasks [11,19]. In contrast, veterans acquire most of their daily dietary intake in a home/community environment similar to the general population $[6,20]$. Numerous studies have reported on the dietary intakes within military and veteran populations [21-25]. However, the data from these studies have not been systematically reviewed and synthesised for a broad range of military and veteran settings, with the exception of where combat rations are consumed for active military personnel [17]. Considering dietary intake in environments where combat rations are not used is more indicative of the habitual diets of active military personnel, it is important that the scope of the evidence is explored.

The purpose of this scoping review was to investigate the use of dietary intake measures of whole diet in military and veteran populations. The primary question was to determine what is known about the assessment and reporting of whole dietary intakes in individuals within military and veteran populations, from a broad range of settings. The secondary question was to evaluate whether assessment and reporting of whole dietary intake of individuals in the military include comparison with current dietary guidelines. These questions were selected to ensure a broad scope of literature was captured [26].

\section{Methods}

A scoping review was chosen to be undertaken for this topic to systematically synthesise the main sources of whole dietary intake data collected within military or military veteran populations. Scoping reviews assist in outlining the current evidence and possible evidence gaps in areas of research. This scoping review adheres to the PRISMA Extension for Scoping Reviews Checklist (PRISMA-ScR Checklist) [27]. 


\subsection{Search Strategy and Study Selection}

The search strategy and databases were selected in consultation with a research librarian and six databases were searched-CINHAL, Cochrane, EMBASE, Medline, Proquest (Military Database), and Scopus. The search strategy consisted of associated terms in term groups; diet and military (Table 1) and included English language studies published from database inception until April 2019. The reference lists of key papers were also searched. The review included all study designs, excluding narrative reviews, case report/series, commentaries, editorials, Letters to the Editor, theses and conference proceedings.

Studies were included if they assessed and reported whole dietary intake data such as food groups, macronutrients and/or micronutrients, reported data exclusively for populations of military personnel or military veterans and included only healthy populations, meaning those personnel without specific disease states (e.g., sickle-cell anaemia, eosonphillic eosophogitis). Studies that included individuals with those conditions were excluded from the review. Studies that reported on dietary intake from supplements Tables S1 and S2 as a primary outcome, or only a single aspect of diet, such as only energy intake or vitamin D intake, were also excluded. The decision to exclude these studies was made due to interest in dietary assessment methods of whole diet, and therefore studies not reporting on multi-nutrient intake were excluded.

Table 1. Database search strategy.

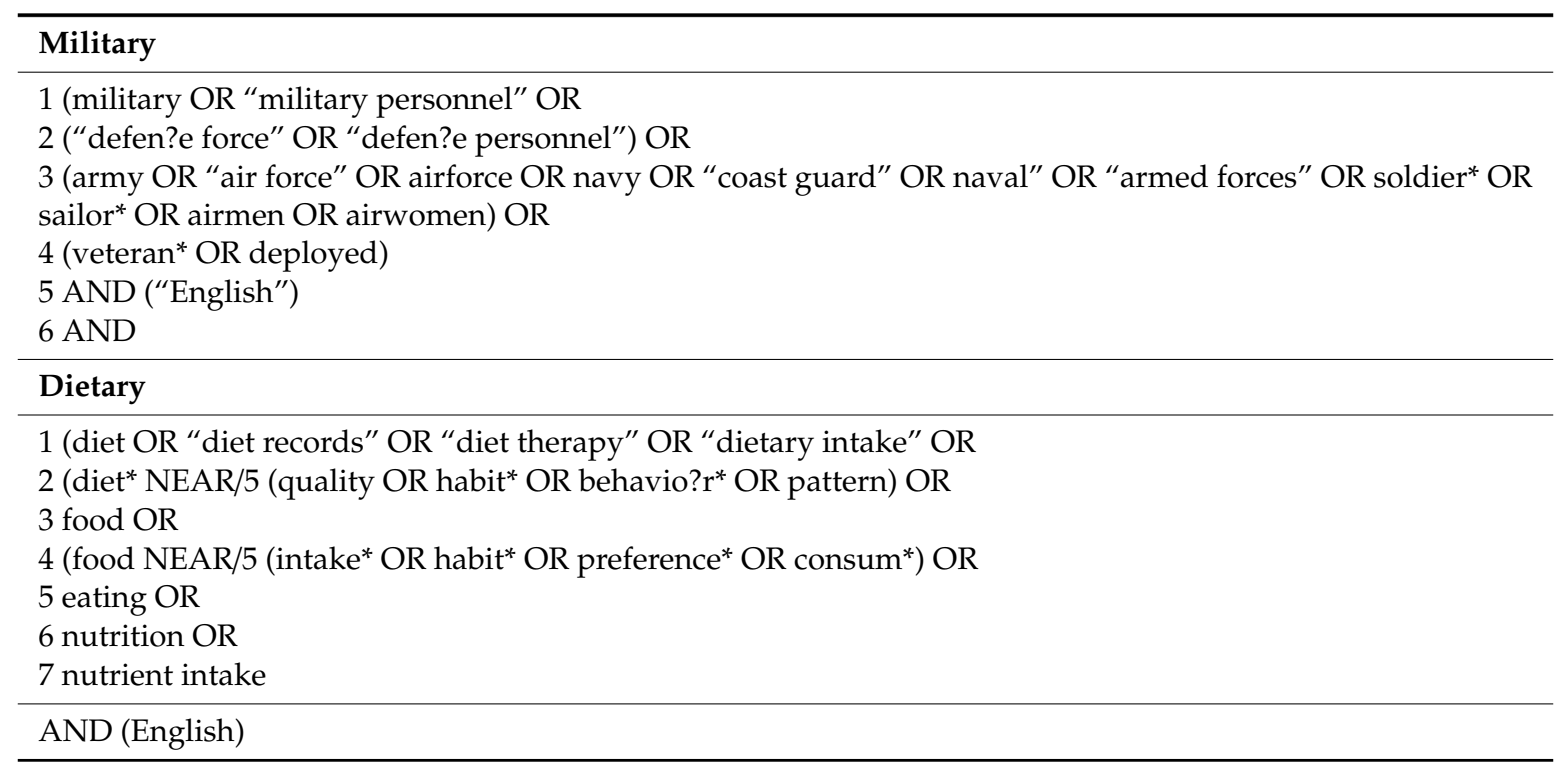

\subsection{Study Selection}

After removal of duplicates (Figure 1), two researchers (RC, TB) conducted title and abstract screening. Regular discussions were had between researchers to ensure consistency was being applied to the screening. Conflicts between searchers were removed by a third party (MR) was consulted and any discrepancies were resolved. A full-text review $(n=329)$ was then completed by two researchers (RC, DC, BB), with any conflicts reviewed by a third researcher (TB).

\subsection{Data Charting}

Data were extracted and charted using a data extraction table designed in consultation with all authors. This was initially piloted with $5 \%$ of studies to ensure all information was being collected consistently. The extraction table was modified after piloting to include both the main outcomes of the study and the reported outcomes specific to nutrition as it was noted that the main outcomes and nutrition outcomes were often separate. Two researchers conducted the data extraction (RC, DC) 
which was then checked by a third researcher (BB) for consistency. Study description and outcomes can be viewed in Table 2. For the purpose of this review studies were classified by dietary assessment method (e.g., food frequency questionnaire (FFQ), 24-hour recall, food records). Studies were defined as multi-method if they included more than one form of dietary assessment method, such as a FFQ with food records, and were classified as validated, if the tool utilised in the study was a standardised measure i.e., diet history or direct observation, or referenced a method validation paper. Methods employed were first checked for validation within a general population, followed by validation within military populations. Studies were classified on the number of dietary intake outcomes reported (i.e., energy, fat, protein etc.) and were categorised into one of three groups: less than five outcomes, five to 10 outcomes, or greater than 10 outcomes. 
Table 2. Included studies.

\begin{tabular}{|c|c|c|c|c|c|}
\hline Author & Study Design & Country & Population & Type of Personnel & No. of Participants \\
\hline \multicolumn{6}{|l|}{ Military populations } \\
\hline Alexander et al. 1987 [28] & Cross-sectional & UK & Navy & Sailors & 2311 \\
\hline Arsenault et al. 2000 [29] & Cross-sectional & USA & Army & Soldiers & 50 \\
\hline Beals et al. 2015 [30] & Cross-sectional & USA & Army & Soldiers & 439 \\
\hline Bedogni et al. 1999 [31] & Pre-Post & Italy & Army & Cadets & 273 \\
\hline Belanger et al. 2016 [32] & Non-controlled trial & USA & Army & Soldiers & $\begin{array}{c}\text { Baseline } \\
n=136 \\
\text { Intervention } n=124\end{array}$ \\
\hline Bingham et al. 2012 [21] & Longitudinal Cohort & Finland & Army & Conscripts & 604 \\
\hline Bingham et al. 2012 [33] & Longitudinal pre-post & Finland & Army & Conscripts & 256 \\
\hline Bingham et al. 2009 [34] & Prospective cohort & Finland & Army & Conscripts & 78 \\
\hline Botelho et al. 2014 [35] & Prospective cohort & Brazil & Army & Soldiers & 92 \\
\hline Buffington et al. 2016 [36] & $\begin{array}{l}\text { Randomised control } \\
\text { trial (RCT) }\end{array}$ & USA & Air Force & Athletes/cadets & 153 \\
\hline Carlson et al. 2013 [37] & Prospective cohort & USA & Army & Soldiers & 53 \\
\hline Cline et al. 1998 [38] & $\begin{array}{l}\text { Retrospective } \\
\text { case-control }\end{array}$ & USA & Army & Soldiers & $\begin{array}{c}\text { Cases } n=63 \\
\text { Control } n=78\end{array}$ \\
\hline Cline et al. 2000 [39] & $\mathrm{RCT}$ & USA & Army & Marines & $\begin{array}{l}\text { Intervention } n=32 \\
\quad \text { Control } n=31\end{array}$ \\
\hline Cole et al. 2018 [40] & $\begin{array}{l}\text { Non-randomised } \\
\text { control }\end{array}$ & USA & Army & Soldiers & 688 \\
\hline Copp et al. 1991 [41] & Cross-sectional & USA & Air Force & Fighter pilots & 30 \\
\hline Crombie et al. 2013 [7] & $\begin{array}{l}\text { RCT with partial } \\
\text { crossover design }\end{array}$ & USA & Army & Active duty soldiers & $\begin{array}{c}\text { Baseline } n=602 \\
\text { Completed study } n=458\end{array}$ \\
\hline DeBolt et al. 1988 [42] & Observational & USA & Navy & SEAL Trainees & 267 \\
\hline Deuster et al. 2003 [43] & Cross sectional & USA & Army & Rangers & 38 \\
\hline
\end{tabular}


Table 2. Cont

\begin{tabular}{|c|c|c|c|c|c|}
\hline Author & Study Design & Country & Population & Type of Personnel & No. of Participants \\
\hline Dwyer et al. 1981 [44] & Prospective cohort & Australia & Armed forces & Recruits & 530 \\
\hline Edwards et al. 1987 [45] & Cross-sectional & England & Army & Recruits & Not reported (NR) \\
\hline Eliasson et al. 2012 [46] & Cross-sectional & USA & Army & Soldiers & 265 \\
\hline Etzion-Daniel et al. 2008 [47] & Prospective cohort & Israel & Army & Infantry and medics & $\begin{array}{c}\text { Karakal females } n=92 \\
\text { Karakal males } n=33 \text { Control } \\
\text { females } n=48\end{array}$ \\
\hline Fallowfield et al. 2019 [48] & Pre and post - Cohort & UK & Army & Soldiers (marines, officers) & $\begin{array}{c}\text { Pilot } n=37 \\
\text { Main study } n=98\end{array}$ \\
\hline Fiedler et al. 1999 [49] & Pre-Post & USA & Air Force & Recruits & $\begin{array}{l}\text { Intervention } n=402 \text { Control } \\
\qquad n=422\end{array}$ \\
\hline Francois et al. 1997 [50] & Cross-sectional & France & Army & Soldiers & $\begin{array}{l}\text { Strasbourg } n=344 \\
\quad \text { Souge } n=1129\end{array}$ \\
\hline Frank et al. 2016 [51] & $\begin{array}{c}\text { Prospective, } \\
\text { longitudinal, cluster } \\
\text { RCT }\end{array}$ & USA & Army & Soldiers & 234 \\
\hline Friedl et al. 1995 [52] & Cross-sectional & USA & Army & Cadets & $\begin{array}{l}1979 n=190 \\
1990 n=205\end{array}$ \\
\hline $\begin{array}{c}\text { Gaffney-Stomberg et al. } 2014 \\
\text { [53] }\end{array}$ & $\mathrm{RCT}$ & USA & Army & Recruits & 168 \\
\hline Gambera et al. 1995 [54] & Randomised trial & USA & Air Force & Active duty air force & $\begin{array}{c}32 \text { Exercise only } n=17 \text { Exercise + } \\
\qquad \operatorname{diet} n=15\end{array}$ \\
\hline Hart et al. 1992 [55] & Cross-sectional & USA & Air Force & F-16 and F-15 pilots & $n=118$ \\
\hline $\begin{array}{c}\text { Herzman-Harari et al. } 2013 \\
\text { [56] }\end{array}$ & $\begin{array}{l}\text { Non-controlled trial } \\
\text { 1-year follow-up }\end{array}$ & Israel & Army & Border Police (soldiers) & $\begin{array}{l}\text { Baseline } n=44 \\
\text { 2-mths } n=43 \\
\text { 4-mths } n=38\end{array}$ \\
\hline Hilgenberg et al. 2016 [8] & Cross-sectional & Brazil & Air Force & Air Force cadets & 166 \\
\hline Ismail et al. 1996 [57] & $\begin{array}{l}\text { Observational } \\
\text { Cross-sectional }\end{array}$ & Malaysia & Army & Soldiers & 20 \\
\hline
\end{tabular}


Table 2. Cont.

\begin{tabular}{|c|c|c|c|c|c|}
\hline Author & Study Design & Country & Population & Type of Personnel & No. of Participants \\
\hline Jackson et al. 1983 [58] & Cross-sectional & USA & Army & Marine service men & 2599 \\
\hline King et al. 1993 [59] & Cross-sectional & USA & Army & Soldiers & 103 \\
\hline Klicka et al. 1996 [60] & Cross-sectional & USA & Army & Cadets & 204 \\
\hline Kono et al. 1996 [61] & Cross-sectional & Japan & Army & Self-Defence forces & 2062 \\
\hline Lutz et al. 2013 [62] & Pre-post & US & Army & Recruits & 135 \\
\hline Lutz et al. 2017 [63] & Cross-sectional & US & Army and air force & Recruits & 834 \\
\hline Lutz et al. 2019 [64] & Cross-sectional & USA & Navy & Marine recruits & 380 \\
\hline Mathew et al. 2004 [65] & Case-control & US & Navy & Sailors & 467 \\
\hline McAdam et al. 2018 [66] & Cross-sectional & USA & Army & Recruits & 111 \\
\hline McClung et al. 2017 [67] & Cross-sectional & US & Army & $\begin{array}{l}\text { Soldiers with rank of } \\
\text { sergeant or below }\end{array}$ & 131 \\
\hline Milne et al. 1980 [68] & Cross-sectional & US & Navy & Sailors & NR \\
\hline Moran et al. 2012 [2] & $\begin{array}{c}\text { Prospective cohort } \\
4 \text { and 6-mth follow-up }\end{array}$ & Israel & Army & Combat recruits & 74 \\
\hline Mullie et al. 2012 [69] & Cross-sectional & Belgium & Army & Soldiers & 1852 \\
\hline Mullie et al. 2015 [70] & Cross-sectional & Belgium & Army & Soldiers & 1699 \\
\hline Mullie et al. 2009 [71] & Validation study & Belgium & Army & Soldiers & 95 \\
\hline Mullie et al. 2016 [22] & Cross-sectional & Belgium & Army & Soldiers & 7252 \\
\hline Mullie et al. 2012 [72] & Cross-sectional & Belgium & Army & Soldiers & 1852 \\
\hline Mullie et al. 2009 [73] & Cross-sectional & Belgium & Army & Soldiers & 1852 \\
\hline Nakayama et al. 2018 [74] & Cross-sectional & USA & $\begin{array}{c}\text { Army, Air Force, } \\
\text { Marines }\end{array}$ & Soldiers, air force, marines & 401 \\
\hline Nkondjock et al. 2010 [75] & Cross-sectional & Central Africa & $\begin{array}{l}\text { All services of the } \\
\text { defence forces }\end{array}$ & Defence force members & 541 \\
\hline Polikandrioti 2009 et al. [23] & Cross-sectional & Greece & Army & Recruits & 1000 \\
\hline
\end{tabular}


Table 2. Cont

\begin{tabular}{|c|c|c|c|c|c|}
\hline Author & Study Design & Country & Population & Type of Personnel & No. of Participants \\
\hline Purvis et al. 2013 [24] & Cross-sectional & US & Army & Soldiers & 13,858 \\
\hline Rahmani et al. 2017 [76] & Cross-sectional & Iran & Army & Infantry soldiers & 246 \\
\hline Ramsey et al. 2013 [6] & Cross-sectional s & US & Army & Soldiers & 39 \\
\hline Royer et al. 2018 [77] & $\begin{array}{l}\text { Cross-sectional } \\
\text { Observational }\end{array}$ & USA & Army & Special Forces & 215 \\
\hline Shams-White et al. 2019 [78] & Cross-sectional & USA & Army and Navy & Not specified & 333 \\
\hline Singh et al. 1988 [79] & Cross-sectional & USA & Navy & Navy SEALS & 16 \\
\hline Smith et al. 2013 [25] & Retrospective cohort & US & $\begin{array}{l}\text { Army, navy, marine } \\
\text { corps and air force }\end{array}$ & Military & 15,747 \\
\hline Smoak et al. 1988 [80] & Cross-sectional & US & Navy & Recruits & 16 \\
\hline Stark et al. 2008 [81] & Cross-sectional & Israel & Air Force & Pilots & 31 \\
\hline Tharion et al. 2004 [82] & $\begin{array}{l}\text { Observational } \\
\text { cross-sectional }\end{array}$ & USA & Army & $\begin{array}{l}\text { Special Forces and } \\
\text { Support Personnel }\end{array}$ & 45 \\
\hline Trent et al. 1988 [83] & Cross-sectional & US & Navy & Sailors & 1013 \\
\hline Uglem et al. 2014 [84] & $\begin{array}{l}\text { Non-randomised } \\
\text { controlled trial } \\
\text { 5-mth follow-up }\end{array}$ & Norway & Army & Recruits & 479 \\
\hline Uglem et al. 2011 [85] & Cross-sectional & Norway & National Guard & Recruits & 578 \\
\hline Uglem et al. 2013 [86] & $\begin{array}{l}\text { Non-randomised } \\
\text { controlled trial } \\
\text { 5-mth follow-up }\end{array}$ & Norway & National Guard & Recruits & 479 \\
\hline Versluis et al. 1973 [87] & Cross sectional & South Africa & Air Force & Air Force & 51 \\
\hline Williamson et al. 2002 [88] & Cohort study & US & Army & Recruits & 92 \\
\hline Young et al. 2017 [89] & $\begin{array}{c}\text { RCT } \\
\text { 10-week follow-up }\end{array}$ & US & Army & Military & 71 \\
\hline
\end{tabular}


Table 2. Cont.

\begin{tabular}{|c|c|c|c|c|c|}
\hline Author & Study Design & Country & Population & Type of Personnel & No. of Participants \\
\hline \multicolumn{6}{|l|}{ Veterans } \\
\hline Balali-Mood et al. 2014 [90] & Cross-sectional & Iran & Veterans & NR & 110 \\
\hline Barboriak et al. 1978 [91] & Cohort observational & USA & Veterans & NR & 51 \\
\hline Becerra et al. 2016 [92] & Cross-sectional & USA & Veterans & NR & 11,011 \\
\hline Chapman et al. 1996 [93] & Prospective cohort & USA & Veterans & All & 209 \\
\hline Ciubotaru et al. 2015 [94] & $\begin{array}{l}\text { Double-blind } \\
\text { placebo-RCT }\end{array}$ & USA & Veterans & Veterans & 115 \\
\hline Gordon et al. 1985 [95] & Cross-sectional & USA & Veterans & Veterans & 73 \\
\hline Hamirudin et al. 2016 [96] & $\begin{array}{c}\text { Observational } \\
\text { cross-sectional 3-mth } \\
\text { follow-up }\end{array}$ & Australia & Veterans & Veterans & 68 \\
\hline Kaye et al. 2015 [97] & $\begin{array}{l}\text { Prospective } \\
\text { Longitudinal }\end{array}$ & USA & Veterans & Veterans & 533 \\
\hline Koutrakis et al. 2019 [98] & Cross-sectional & USA & Veterans & Veterans & 183 \\
\hline Littman et al. 2015 [99] & Cross-sectional & US & Veterans & Veterans & 150 \\
\hline Mehta et al. 2016 [100] & Longitudinal & US & Veterans & Veterans & 839 \\
\hline Nosova et al. 2015 [101] & Cross-sectional & US & Veterans & Veterans & 88 \\
\hline Park et al. 2009 [20] & Prospective cohort & US & Veterans & Veterans & 586 \\
\hline Seddon et al. 2006 [102] & Prospective Cohort & US & Veterans & Veterans & 1362 (681 twins) \\
\hline Shahnazari et al. 2013 [103] & $\begin{array}{c}\text { RCT } \\
\text { 6-mth follow-up }\end{array}$ & US & Veterans & Veterans & 60 \\
\hline Vidal et al. 2015 [104] & Case-control & US & Veterans & Veterans & 430 \\
\hline Wang et al. 2017 [105] & $\begin{array}{c}\text { Prospective, } \\
\text { longitudinal cohort } \\
\text { 21-year follow-up }\end{array}$ & US & Veterans & Veterans & 983 \\
\hline Young et al. 1992 [106] & Cross-sectional & US & Veterans & Veterans & 572 \\
\hline
\end{tabular}




\section{Results}

\subsection{Search Results}

The search strategy identified 11,567 citations (Figure 1). After removal of duplicates, 9920 citations were screened. Following title and abstract review, 311 studies underwent full text screening, of which 233 studies were excluded (Figure 1). The main reasons for study exclusions were; study design ( $n=106,44 \%$ ) e.g., if the study did not include quantitative dietary intake measures, or study outcomes $(n=52,21 \%)$ e.g., if the study reported energy expenditure outcomes as opposed to dietary energy or nutrient intake outcomes
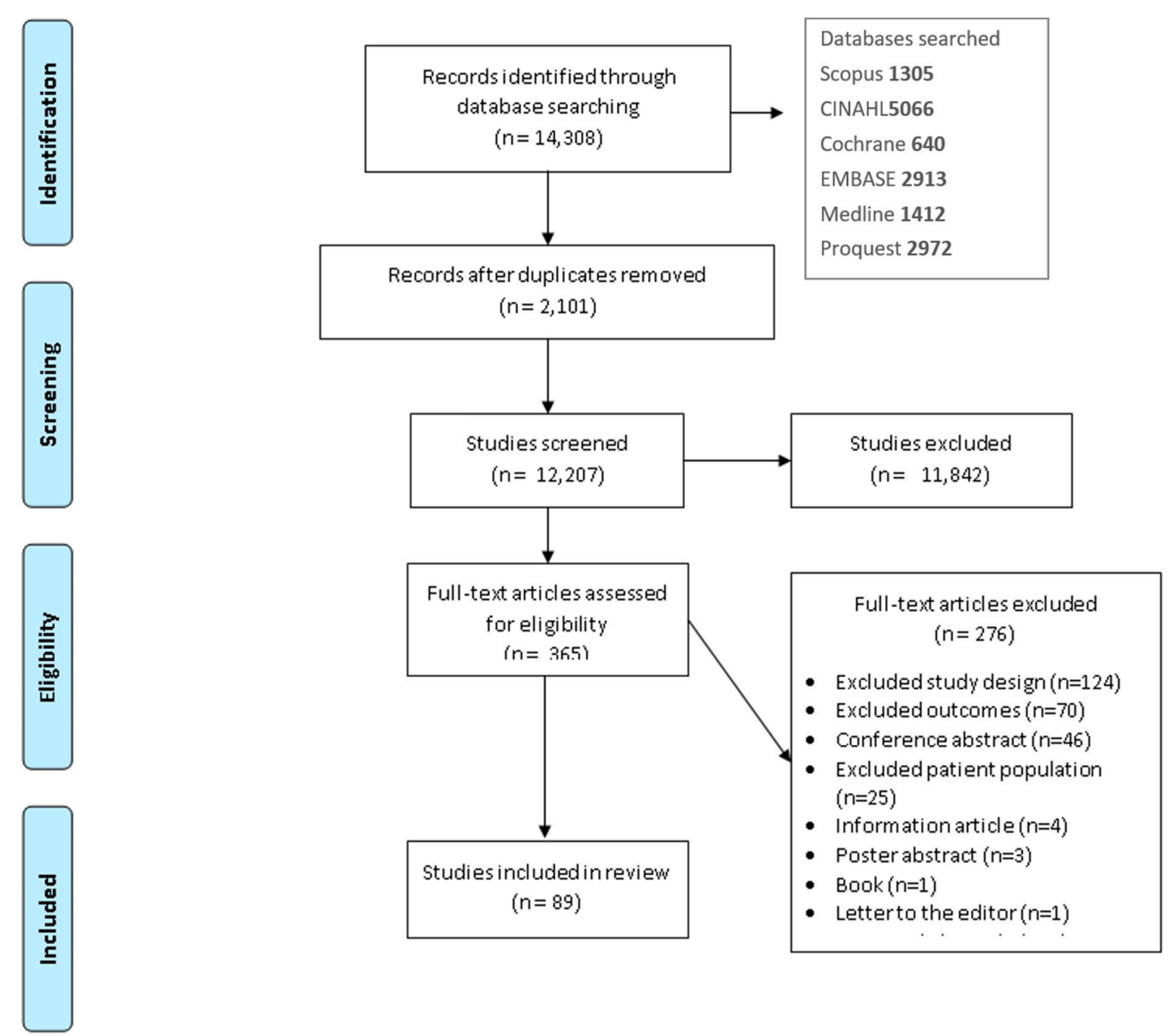

Figure 1. Search strategy process.

\subsection{Study Designs}

Of the 89 studies included, 68 were observational studies including 50 (56\%) cross-sectional studies $[6,8,22-24,28,30,31,35,37,41-43,45,46,50,52,55,57-61,63,64,66,68,70,72-83,85,87,89,90,92,95,96$, 98,99,101,106], 10 (11\%) prospective cohort studies [2,20,34,37,44,47,91,93,102], two (2\%) prospective longitudinal cohort studies [97,105], and two (2\%) retrospective cohort study $[25,100]$. There was one (1\%) of each study design for longitudinal cohort [21], validation study [71], cohort study [88], and retrospective cross-sectional study [29]. Twenty-one of the studies were interventions including eight (9\%) randomised control trials $[7,36,39,51,53,89,94,103]$, four $(4 \%)$ pre-post design studies $[21,48,49,62]$, three $(3 \%)$ non-randomised control trials $[40,84,86]$, two $(2 \%)$ case-control trials $[65,104]$, and two $(2 \%)$ 
non-controlled trial [32,56]. There was one (1\%) of each study design for retrospective case-control trial [38] and randomised trial [54].

\subsection{Study Location}

The year of publication of studies ranged from 1973-2019, with 63 (71\%) of the studies being published from 2000 onwards [2,6-8,20-25,29,30,32,34-37,39,40,43,46-48,51,53,56,62-66,70-78,81,82,8486,88-90,92,94,96-105]. The continent most frequently studying the dietary intake of their military and veterans was North America. All North American sudies were conducted in the USA, with almost two thirds $(n=57,64 \%)$ of included studies originating from this country $[6,7,20,24,25,29,30,32,36-43,46$, 49,51-55,58-60,62-66,68,74,77-80,82,83,88,89,91-95,97-106]. The remaining studies were carried out in Europe including Belgium $(n=6,7 \%)$ [22,70-73], Finland $(n=3,3 \%)$ [21,34], the United Kingdom $(n=3,3 \%)[28,45,48]$, Norway $(n=3,3 \%)[62,94,96]$, Italy $(n=1,1 \%)$ [31], Greece [23], and France $(n=1,1 \%)$ [50]. Asia included studies in Israel $(n=4,4 \%)[2,47,56,81]$, Iran $(n=2,2 \%)[76,90]$ Malaysia $(n=1,1 \%)$ [57], and Japan $(n=1,1 \%)$ [61]. Two studies were undertaken in Australia $(2 \%)[44,96]$. Africa included studies from Cameroon $(n=1,1 \%)$ [75], and South Africa $(n=1,1 \%)$ [87]. In South America two studies were undertaken in Brazil $(2 \%)[8,35]$.

\subsection{Participant Characteristics}

The participant numbers included in the 89 studies ranged from $16 \mathrm{t} 15,747$ personnel, with the average number of personnel studied being 218. One study did not report on participant numbers [45]. Forty-five of the 89 studies included male personnel (51\%) [2,20,21,23,28,31,34,35,37,39, $41,42,44,48,55,58,61,66,70-73,76,77,79-87,90,91,93,94,97,100,102,104-106]$, and approximately a third of the other studies included both male and female personnel $(n=35,39 \%)[6-8,22,24,25,30,37,40$, $45-47,49,51-54,60,62-65,68,74,75,78,88,89,92,95,96,98,99,101,103]$. Female personnel were exclusively studied in five studies $(6 \%)[29,36,38,56,59]$, and four studies $(5 \%)$ did not report on the gender of the personnel included $[32,43,50,57]$. Research into female military personnel increased post-2000 with $31 \%$ $(n=28)[6-8,22,24,25,30,37,40,46,47,51,53,62-65,74,75,78,88,89,92,96,98,99,101,103]$ of studies reporting on outcomes for male and female personnel from 2000-2019 and 3\% $(n=3)[29,36,56]$ reporting solely on female personnel from 2000-2016. From 2017-2019 there have been no studies that have included exclusive female populations.

The military population most frequently studied, in descending order, was the army with $n=48$ (54\%) [2,6,7,21-24,29-32,34,35,37-40,43-48,50-53,56-62,66,70-73,76,77,82,84,88,89], followed by veterans $n=18$ (20\%) [20,90-106], navy $n=8(9 \%)[28,42,64,65,68,79,80,83]$, air force $n=8$ $(9 \%)[8,36,41,49,54,55,81,87]$, and National Guard $n=2(2 \%)[85,86]$, and five $(6 \%)$ studies included a combination of different military populations $[25,63,74,75,78]$. One of the most frequently studied sub-groups of the army are those undertaking basic training or cadet training $(n=15 / 48,31 \%)[2,23,31$, $44,45,52,53,60,62,63,66,84-86,88]$.

\subsection{Intervention Studies}

There were $15(17 \%)$ [7,21,32,36,38,39,49,51,53,54,56,84,89,103] intervention studies of which five included a follow-up component [56,84,86,89,103] ranging from 10 weeks to one year. The population types that included intervention studies were army $(n=9)[7,21,32,38,51,53,56,84,89]$, air force $(n=3)[36,49,54]$, veterans $(n=1)$ [103], National Guard $(n=1)$ [86], and Navy Marines $(n=1)$ [39]. The most commonly studied type of military personnel in included studies were soldiers $(n=28$, $31 \%)[6,7,22,24,29,32,35,37,38,45,46,48,50,51,53,56,57,59,62,70-74,76,88]$ followed by veterans $(n=14$, $16 \%)[20,94-106]$, and military new recruits $(n=9,10 \%)[2,23,44,49,63,66,84-86]$. 


\subsection{Dietary Assessment Methods}

A range of dietary intake methodologies were used with studies incorporating one dietary assessment method $(n=76,85 \%)$ [2,6-8,20,22-25,28,29,32,34-40,42-51,53,55-66,70,72-92,94,97-106] or multiple methods $(n=13,15 \%)[21,30,31,37,41,52,54,68,71,93,95,96]$.

\subsubsection{Food Frequency Questionnaires (FFQs)}

The most frequent methodology used in included studies was FFQs $(n=40,45 \%)[2,6,20,21$, $37,38,41,43,44,47,51,53,56,62-65,70-76,78,90,93,96-106]$ ranging in length from eight to 150 items and administered from once per study up to multiple over a 17-year period. The personnel types to commonly use the FFQ for dietary intake collection were army $(n=23 / 40,58 \%)[2,6,21,37,38,43,44,47$, $51,53,56,62,63,70-76,78]$ and veterans $(n=14,35 \%)[20,90,93,96-106]$.

\subsubsection{Twenty Four-Hour Recalls}

The studies that used 24-hour recall $(n=8,9 \%)[30,34,41,77,81,93-95]$ varied in the number of times administered. Four studies administered a 24-hour recall once throughout the study $[30,77,81,95]$, one study administered two 24-hour recalls at two time points [36], one study the method was administered twice in the main group and two to three times in a subset of participants [94], another had all participants undertake a 24-hour recall three times with a subset undertaking a further three recalls [93]. One study administered four 24-hour recalls [41]. The use of a multiple-pass dietary recall (MPR) approach, within the administration of 24-hour recall, was only reported in one study [77].

\subsubsection{Food Records}

Food records $(n=8,9 \%)[8,34,48,52,68,84-86]$ ranging in duration including three days $(n=1)$ [8], four days $(n=4)$ [48,84-86], seven days $(n=1)$ [52], and 14 days $(n=1)$ [68]. One study consisting of two sub-studies required one three-day food record and one four-day food record [34]. Four studies were identified as using biomarkers to determine dietary intake [37,53,64,93].

\subsection{Validity of Dietary Assessment Methods}

Of the dietary intake methodologies used, 66 (74\%) [2,6-8,20,21,24,30-32,35,37-40,43,46-51,53, 54,56-60,62-65,68,70-78,80-82,84-86,88,91-93,97-106] were reported as validated methods, including direct observation, 24-hour recall and FFQs or well recognised methods including, dietary records, and diet history $[107,108]$. Only two studies $(2 \%)$ were validated specifically for military populations [58,59]. Twenty three studies (26\%) did not report validatio [22,23,25,28,29,34,36,41,42,44,45,52,55,61,66,79,83, $87,89,90,94-96]$.

\subsection{Dietary Outcomes}

Of the 89 studies, 13 (15\%) reported less than five dietary outcomes [21,36,46,48,57,59,72,84, $92,95,98,106], 35(39 \%)$ reported five to $10[8,20,22-25,31,32,35,37,43,45,47,49,50,52-55,58,64-66,68$, $73,77,78,85,86,88,89,94,101,102,104]$, and 41 (46\%) reported more than 10 dietary outcomes, which were mostly nutrient profiles $[2,6,7,28-30,34,37-42,44,51,56,60-63,70-72,74-76,79-83,87,90,91,93,96,97$, $99,100,103,105]$ and less often food based outcomes. Seventy three of 89 studies $(82 \%)[2,6-8,20-25,29-$ 32,34-40,42-44,46-49,51-57,59,61,63-66,70,72-77,79,81-83,85,88-90,92-106] assessed anthropometric data in addition to dietary assessment. The most commonly used anthropometric assessment was body mass index (BMI) $(n=60,67 \%)[2,6-8,20-25,29-32,34,35,37,38,40,42,44,46,47,49,51,53,54,56,57,61$, 63-65,70,72-76,81,85,88-90,92-94,96-106]. The main dietary outcomes reported were a combination of macronutrients; carbohydrate, protein, fat, and alcohol $(n=66,74 \%)[2,6-8,28-32,34-45,47-60,62$, 63,65,66,68,70-72,74,76-79,81-83,87,89-91,93-97,102-104,106]. Total energy intake was also frequently measured $(n=59,66 \%)[2,6,7,20,28-32,34,35,37-43,48-51,53-60,65,66,68,70-72,74-77,79,81,82,88-91,93-$ $97,100,102-106]$. Alcohol was the most individually investigated source of energy $(n=19,21 \%)$ and 
quantified mainly as grams consumed per day or as a total percentage of energy intake $[6,20,25,34,43$, 50,60-62,70,71,75,79,82,83,96-98,102]. Micronutrients were reported in 46 (52\%) [2,6,20,28-30,32,34,35, 37-39,41,42,45,47,49-53,56,58,60,63,68,70,71,74,75,78-82,87,90,91,93,96-98,101-103] studies, and food groups reported 32 times (36\%) [7,21-25,29,34,40,46,49,54,62-65,73-76,78,83-86,88,92,99,100,103,105]. Fibre intake was reported in 21 studies $(24 \%)[8,31,34,35,37,38,45,50,54,56,65,71,72,75,81,90,94,96,97$, 101,103].

\subsection{Comparison to Dietary Guidelines}

Fifty three $(60 \%)$ of the 89 studies reported a comparison with country-specific dietary guidelines $[2,6,7,24,25,28,30,32,34,35,37,39,40,42,47-49,51,52,54-60,62,63,66,68,72-74,76-84,86,87,91,94$, 96-98,101,103,105]. Of these 39 (44\%) compared with general dietary guidelines [7,24,25,28,35, $37,40,42,49,51,54,55,57,58,62,63,66,68,70,72-74,76-78,80,82-84,86,87,91,94,96-98,101,103,105]$, one $(1 \%)$ compared with sports nutrition guidelines [30]. Very few studies $(n=1416 \%)$ specifically mentioned comparison with the military guidelines $[2,6,32,34,37,39,47,48,52,56,59,60,79,81]$.

\section{Discussion}

The aim of this scoping review was to provide a broad overview of the dietary assessment methods used to assess the whole dietary intakes of military personnel and military veterans with fresh food access in a broad range of settings. The review identified 89 studies, of which 71 were conducted with active military personnel, with many published since 2010 indicating increased recognition of nutrition in the maintenance of health and military performance of personnel [109]. Most of the studies were based in the USA and were carried out in garrison settings and conducted less often in free-living military groups. Macronutrients were the most reported dietary outcome and the majority of studies reported a comparison with dietary counties. Despite the amount of research dedicated to developing military specific dietary guidelines, most studies did not compare against military specific guidelines.

Across all studies, FFQs were the most commonly used dietary intake method. FFQs have been shown to be a useful tool in the study of non-military populations, however, most FFQs have been designed for use in the general population, or for specific disease states [110]. Moreover, while most studies used validated tools, only two were reported to be validated in military populations. It is important to carry out such studies given the food lists within dietary assessment tools, such as FFQs, should be population-specific where possible. In 2009, Mullie et al. [71] developed a semi quantitative FFQ with 150 food items specific for military men, which was reported to reliably determine the dietary intake of military men. However, this tool was validated specifically within administrative military personnel and may not be valid in more intensive military settings [71]. Of the included studies, biomarkers used for validation purposes as objective measures of dietary intake were used in four studies; doubly-labelled water [37] and metabolites including alpha-carotene and beta-carotene $[53,64,93]$. This highlights the need for further research to validate self-reported dietary intake using objective measures rather than validating against other self-reported measures which have the same reporting bias. There was no apparent relationship between diet assessment method and study design.

Research has shown that between four to eight administrations of MPR, 24-hour recalls are required to minimise error in dietary intake data, with the inclusion of weekends or days off, to cover the change in intake [111-113]. Three of the studies included used the automated self-assessment 24-hour recall method at only one time point which is a limited reflection of usual dietary intake [111,113]. Wherever practicable, dietary research within military and military veteran populations should consider using the 24-hour MPR method over non-consecutive days to obtain data more likely to be reflective of habitual intake $[114,115]$. Recent research suggests combining methods of dietary intake collection is best to reduce the limitations of individual methodologies [113].

In this current review, total energy intake and macronutrients, including alcohol, were the most common dietary outcomes reported, with other aspects of dietary intake reported less often including 
diet quality. More specifically, alcohol consumption was the most commonly reported outcome component and was most often assessed through FFQs. This is an important area of research, given alcohol misuse is suspected to be attributed to increased stress exposure in military service, in particular those with post-traumatic stress disorder (PTSD) [116].

Results of this review show that army personnel (soldiers) is by far the most studied military population when it comes to the assessment of dietary intake. This could be contributed to army branches being the largest military branches in countries such as the USA where the majority of studies arise from, in addition to, Britain and Australia [117-119]. Armies are diverse and generally include groups of occupations from those directly involved in warfighting such as infantry, artillery, cavalry, and special forces, to those supporting front-line warfighters, such as Combat Engineers [14,120]. One of the most frequently studied sub-groups of the Army were those undertaking basic training or cadet training, which may be due to new recruits being placed in very physically demanding situations with increased nutrition requirements. The USA contributes the majority of research into the area of dietary intake amongst its military branches with $62 \%$ of studies originating from this country. This may be reflective of larger military groups, or higher access to military research funding.

When compared to veteran populations, the numbers of all actively serving personnel are much less by comparison [119]. For example, in the USA veteran numbers are reported at 20 million compared to around 400,000 currently serving in the US army [117]. In this current review, less than $25 \%$ of all studies included participants from this large veteran population indicating a large research gap for assessing and improving the diets of those in military veteran groups. The veteran population have differing nutritional needs and requirements post-discharge including transition to the civilian community, different accommodation environments, a more sedentary lifestyle in addition to high rates of mental illness, disability, and health conditions in general, thus it has been shown that the USA veteran population has an increased burden of disease when compared to non-veteran populations [121]. Given sup-optimal dietary intake is a leading contributor to disease, it is likely to contribute to a higher prevalence of ill health, or overweight and obesity rates of veterans, making this a research priority area $[117,122]$. A number of studies have demonstrated that military populations are experiencing a trend towards being increasingly obese, which mirrors the pattern among the general population [123]. A cross-sectional study undertaken by Breland et al. (2017) found the prevalence of obesity amongst veteran population in the USA was $41 \%$ (44\% females, $41 \%$ males). Similarly, in a USA cohort study of the military, obesity among service members was $20 \%$, and significantly higher among veterans (32\%). A 2011 Australian Senate Estimates Brief titled “Obesity in Defence" stated that approximately $15 \%$ of Australian Defence Force personnel had a BMI in the obese range.

The current review also found a marked increase in studies investigating females only from 2000 onwards, which is important as $16 \%$ of the currently enlisted USA Military are female, an increase of $13 \%$ since voluntary military service commenced in the USA [124]. Studies regarding the dietary intake of female military members are notably less in numbers than those with a focus on male members, however, this has been increasing steadily post-2000. It has previously been reported by Goldzweig et al. (2006), that since 2000 there has been an increase in female military recruits who now make up $20 \%$ of total new recruits. This increase also coincides with the decision in 2013 by countries, including the USA and Australia, to open frontline combat roles to women $[125,126]$. The increased numbers of female military personnel has been recognised by the US Department of Veterans Affairs, and may explain the reason for the increase in focus on the specific dietary and health needs of female military recruits [127]. Another reason may be the unique nutrition requirements of females in the military. Many women in the US do not meet the Recommended Dietary Allowances of important nutrients such as calcium and iron, and in a military setting with increased physical training, these inadequate intakes could lead to long-term negative health outcomes [59].

This scoping review has several strengths including a comprehensive systematic search and review protocol, including a detailed data extraction process. Moreover, military experts were consulted at all stages in the development of this review to provide input to ensure data and reporting were accurate 
and relevant. Limitations include that only studies in English were included which may have limited the extent of military dietary data access. As such, non-English studies from countries such as China and Russia, which have large military spends and large military services, were not included. The current review reflects only those databases searched and may not reflect unpublished or other military specific journals not commonly available to researchers. Grey literature was also not searched, further limiting full access to published dietary intake data.

In conclusion, dietary intake in military settings is most commonly assessed via the FFQ and 24-hour recall methodologies, however not all tools used were specifically validated for military populations. Dietary intake reporting was mainly focused around overall individual energy intake, and the intake of macronutrients including carbohydrates, proteins, fats, and alcohol. Comparison to dietary guidelines was used in the majority of studies, however the comparison to specific military dietary guidelines is minimal.

Supplementary Materials: The following are available online at http://www.mdpi.com/2072-6643/12/3/769/s1, Table S1: Characteristics of included studies, Table S2: Study outcome characteristics

Author Contributions: Conceptualization, R.A.C., T.L.B. and M.E.R.; methodology, R.A.C., T.L.B. and M.E.R.; validation, formal analysis, R.A.C., B.B., D.H.C. and T.L.B.; writing-original draft preparation, R.A.C.; writing-review and editing, R.A.C., B.B., D.H.C., M.E.R. and T.L.B. All authors have read and agreed to the published version of the manuscript.

Funding: This research received no external funding.

Acknowledgments: The authors acknowledge Debbie Booth, The Faculty of Health and Medicine Librarian, for her assistance with the developing the search strategy.

Conflicts of Interest: The authors declare no conflict of interest.

\section{References}

1. Barringer, N.D.; Pasiakos, S.M.; McClung, H.L.; Crombie, A.P.; Margolis, L.M. Prediction equation for estimating total daily energy requirements of special operations personnel. J. Int. Soc. Sports Nutr. 2018, 15. [CrossRef]

2. Moran, D.S.; Heled, Y.; Arbel, Y.; Israeli, E.; Finestone, A.; Evans, R.K.; Yanovich, R. Dietary intake and stress fractures among elite male comnat recruits. J. Int. Soc. Sports Nutr. 2012, 9, 6. [CrossRef] [PubMed]

3. McAdam, J.S.; McGinnis, K.D.; Beck, D.T.; Haun, C.T.; Mumford, P.W.; Roberson, P.A.; Young, K.C.; Lohse, K.R.; Lockwood, C.M.; Roberts, M.D.; et al. Effect of whey protein supplementation on physical performance and body composition in army initial entry training soldiers. Nutrients 2018, 10, 1248. [CrossRef] [PubMed]

4. Skiller, B.; Booth, C.; Coad, R.; Forbes-Ewan, C. Assessment of Nutritional Status and Fatigue Among Army Recruits during the Army Common Recruit Training Course: Part a: Catering Services and Diet; Defence, D., Ed.; CBRN Defence Centre: Victoria, UK, 2005.

5. Naghii, M.R. The importance of body weight and weight management for military personnel. Mil. Med. 2006, 171, 550-555. [CrossRef] [PubMed]

6. Ramsey, C.B.; Hostetler, C.; Andrews, A. Evaluation the nutrition intake of U.S. Military service members in garrison. Mil. Med. 2013, 178, 1285-1290. [CrossRef] [PubMed]

7. Crombie, A.P.; Funderburk, L.K.; Smith, T.J.; McGraw, S.M.; Walker, L.A.; Champagne, C.M.; Allen, H.R.; Margolis, L.M.; McClung, H.L.; Young, A.J. Effects of modified foodservice practices in military dining facilities on ad libitum nutritional intake of us army soldiers. J. Acad. Nutr. Diet. 2013, 113, 920-927. [CrossRef]

8. Hilgenberg, F.E.; Santos, A.S.; Silveira, E.A.; Cominetti, C. Cardiovascular rick factors and food consumption of cadets from the brazilian air force academy. Cienc. Saude Coletiva. 2016, 21, 1165-1174. [CrossRef]

9. Hollander, I.E.; Bell, N.S.; Sharp, M. Physical Demands of Army Military Occupational Specialties: Constructing and Applying a Crosswalk to Evaluate the Relationship between Occupational Physical Demands and Hospitlization; Social Sectors Development Strategies, Inc.: Boston, MA, USA, 2008.

10. Valk, P.J.L.; Pasman, W. Physical Demands, Mental Performance and Food Components in Military Settings; TNO Defence, Security and Safety: Soesterberg, The Netherlands, 2005. 
11. Baker-Fulco, C.J.; Bathalon, G.P.; Bovill, M.E.; Lieberman, H.R. Military Dietary Reference Intakes: Rationale for Tabled Values; Medicine, U., Ed.; Army Research Inst of Environmental Medicine: Natick, MA, USA, 2001.

12. Departments of the Army the Navy and the Air Force. Nutrition \& Menu Standards for Human Performance Optimization; Departments of the Army the Navy and the Air Force: Washington, DC, USA, 2017.

13. Office of Disease Prevention and Health Promotion. Dietary Guidelines. Secondary Dietary Guidelines. Available online: https://health.gov/dietaryguidelines/ (accessed on 9 April 2018).

14. Departments of the Army the Navy and the Air Force. Army Regulation 40-Nutrition Standards and Education; Departments of the Army the Navy and the Air Force: Washington, DC, USA, 2001.

15. Forbes-Ewan, C. Australian Defence Force Nutritional Requirements in the 21st Century (Version 1); Defence, D., Ed.; Human Protection and Performance Division: Canberra, Australia, 2009.

16. Nutrition Science and Food Standards for Military Operations; NATO Research and Technology Organization: Neuilly, France, 2010.

17. Tassone, E.C.; Baker, B.A. Body weight and body composition changes during military training and deployment involving the use of combat rations: A systematic literature review. Br. J. Nutr. 2017, 117, 897-910. [CrossRef]

18. Tharion, W.J.; Lieberman, H.R.; Montain, S.J.; Young, A.J.; Baker-Fulco, C.J.; DeLany, J.P.; Hoyt, R.W. Energy requirements of military personnel. Appetite 2005, 44. [CrossRef]

19. Margolis, L.M.; Rood, J.; Champagne, C.M.; Young, A.J.; Castellani, J.W. Energy balance and body composition during us army special forces training. Appl. Physiol. Nutr. Metab. 2013, 38, 396-400. [CrossRef]

20. Park, S.K.; Tucker, K.L.; O’Neill, M.S.; Sparrow, D.; Vokonas, P.S.; Hu, H.; Schwartz, J. Fruit, vegetable, and fish consumption and heart rate variability: The veterans administration normative aging study. Am. J. Clin. Nutr. 2009, 89, 778-786. [CrossRef] [PubMed]

21. Bingham, C.M.; Lahti-Koski, M.; Puukka, P.; Kinnunen, M.; Jallinoja, P.; Absetz, P. Effects of a healthy food supply intervention in a military setting: Positive changes in cereal, fat and sugar containing foods. Int. J. Behav. Nutr. Phys. Act. 2012, 9. [CrossRef] [PubMed]

22. Mullie, P.; Deliens, T.; Clarys, P. Relation between sugar-sweetened beverage consumption, nutrition, and lifestyle in a military population. Mil. Med. 2016, 181, 1335-1339. [CrossRef] [PubMed]

23. Polikandrioti, M.; Kotronoulas, G.; Liveri, D.; Giovaso, S.; Varelis, G.; Kyritsi, E. Body mass index, central obesity, and dietary patterns in a group of young adult men. Health Sci. J. 2009, 3, 54-63.

24. Purvis, D.L.; Lentino, C.V.; Jackson, T.K.; Murphy, K.J.; Deuster, P.A. Nutrition as a component of the performance triad: How healthy eating behaviors contribute to soldier performance and military readiness. US Army Med. Dep. J. 2013, Oct-Dec, 66-78.

25. Smith, T.J.; Dotson, L.E.; Young, A.J.; White, A.; Hadden, L.; Bathalon, G.P.; Funderburk, L.; Marriott, B.P. Eating patterns and leisure-time exercise among active duty military personnel: Comparison to the healthy people objectives. J. Acad. Nutr. Diet. 2013, 113, 907-919. [CrossRef]

26. Arksey, H.; O’Malley, L. Scoping studies: A methodological framework. Int. J. Soc. Res. 2005, 8, 19-32. [CrossRef]

27. Tricco, A.C.; Lillie, E.; Zarin, W.; O’Brien, K.K.; Colquhoun, H.; Levac, D.; Moher, D.; Peters, M.D.J.; Horsley, T.; Weeks, L.; et al. Prisma extension for scoping reviews (prisma-scr): Checklist and explanation. Ann. Intern. Med. 2018, 169, 467-473. [CrossRef]

28. Alexander, D.C.; Doyle, W. A nutritional analysis of food provided to royal naval personnel at sea. Hum Nutr. Appl. Nutr. 1987, 41, 193-203.

29. Arsenault, J.E.; Cline, A.D. Nutrient intakes and characteristics of normal weight, female military personnel consuming foods reduced in fat or energy content. Appetite 2000, 34, 227-233. [CrossRef]

30. Beals, K.; Darnell, M.E.; Lovalekar, M.; Baker, R.A.; Nagai, T.; San-Adams, T.; Wirt, M.D. Suboptimal nutritional characteristics in male and female soldiers compared to sports nutrition guidelines. Mil. Med. 2015, 180, 1239-1246. [CrossRef] [PubMed]

31. Bedogni, G.; Bernini Carri, E.; Gatti, G.; Severi, S.; Poli, M.; Ferrari, F.; Battistini, N. Comparison of food composition tables and direct chemical analysis for the assessment of macronutrient intake in a military community. Int. J. Food Sci. Nutr. 1999, 50, 73-79. [CrossRef] [PubMed]

32. Belanger, B.A.; Kwon, J. Effectiveness of healthy menu changes in a nontrainee military dining facility. Mil. Med. 2016, 181, 82-89. [CrossRef] [PubMed] 
33. Bingham, C.M.; Lahti-Koski, M.; Absetz, P.; Puukka, P.; Kinnunen, M.; Pihlajamaki, H.; Sahi, T.; Uutela, A.; Jallinoja, P. Food choices and health during military service: Increases in sugar- and fibre-containing foods and changes in anthropometric and clinical risk factors. Public Health Nutr. 2012, 15, 1248-1255. [CrossRef] [PubMed]

34. Bingham, C.M.; Ovaskainen, M.L.; Tapanainen, H.; Lahti-Koski, M.; Sahi, T.; Paturi, M. Nutrient intake and food use of finnish conscripts in garrison, on leave, and in encampment conditions. Mil. Med. 2009, 174, 678-684. [CrossRef]

35. Botelho, R.B.A.; Avena, F.; Veras, M.; Zandonadi, R.P. Nutritional adequacy of meals offered and consumed by soldiers of the brazilian army. Rev. Nutr. 2014, 27, 229-239. [CrossRef]

36. Buffington, B.C.; Melnyk, B.M.; Morales, S.; Lords, A.; Zupan, M.R. Effects of an energy balance educational intervention and the cope cognitive behavioral therapy intervention for division i U.S. Air force academy female athletes. J. Am. Assoc. Nurse Pract. 2016, 28, 181-187. [CrossRef]

37. Carlson, A.R.; Smith, M.A.; McCarthy, M.S. Diet, physical activity, and bone density in soldiers before and after deployment. US Army Med. Dep. J. 2013, Apr-Jun, 25-30.

38. Cline, A.D.; Jansen, G.R.; Melby, C.L. Stress fractures in female army recruits: Implications of bone density, calcium intake, and exercise. J. Am. Coll. Nutr. 1998, 17, 128-135. [CrossRef]

39. Cline, A.D.; Tharion, W.J.; Tulley, R.T.; Hotson, N.; Lieberman, H.R. Influence of a carbohydrate drink on nutritional status, body composition and mood during desert training. Aviat. Space Environ. Med. 2000, 71, 37-44.

40. Cole, R.E.; Bukhari, A.S.; Champagne, C.M.; McGraw, S.M.; Hatch, A.M.; Montain, S.J. Performance nutrition dining facility intervention improves special operations soldiers' diet quality and meal satisfaction. J. Nutr. Educ. Behav. 2018, 500, 993-1004. [CrossRef] [PubMed]

41. Copp, E.K.; Green, N.R. Dietary intake and blood lipid profile survey of fighter pilots at tyndall air force base. Aviat Space Environ. Med. 1991, 62, 837-841. [PubMed]

42. DeBolt, J.E.; Singh, A.; Day, B.A.; Deuster, P.A. Nutritional survey of the us navy seal trainees. Am. J. Clin. Nutr. 1988, 48, 1316-1323. [CrossRef] [PubMed]

43. Deuster, P.A.; Sridhar, A.; Becker, W.J.; Coll, R.; O’Brien, K.K.; Bathalon, G.; Health assessment of U.S. Army rangers. Mil. Med. 2003, 168, 57-62. [PubMed]

44. Dwyer, T.; Calvert, G.D.; Baghurst, K.I.; Leitch, D.R. Diet, other lifestyle factors and hdl cholesterol in a population of australian male service recruits. Am. J. Epidemiol. 1981, 114, 683-696. [CrossRef]

45. Edwards, J.; Thomson, J. British army diet. NFS 1987, 87, 18-21. [CrossRef]

46. Eliasson, A.; Kashani, M.; Dela Cruz, G.; Vernalis, M. Readiness and associated health behaviors and symptoms in recently deployed army national guard solders. Mil. Med. 2012, 177, 1254-1260. [CrossRef] [PubMed]

47. Etzion-Daniel, Y.; Constantini, N.; Finestone, A.S.; Shahar, D.R.; Israeli, E.; Yanovich, R.; Moran, D.S. Nutrition consumption of female combat recruits in army basic training. Med. Sci. Sports Exerc. 2008, 40 (Suppl. 11), S677-S684. [CrossRef]

48. Fallowfield, J.L.; Delves, S.K.; Hill, N.E.; Lanham-New, S.A.; Shaw, A.M.; Brown, P.E.H.; Bentley, C.; Wilson, D.R.; Allsopp, A.J. Serum 25-hydroxyvitamin d fluctuations in military personnel during 6-month summer operational deployments in afghanistan. Br. J. Nutr. 2019, 121, 384-392. [CrossRef]

49. Fiedler, E.R.; Cortner, D.M.; Ktenidis, H.; Balch, M. Healthy eating in practice: The u.S. Air force demonstration at basic military training. Appl. Prev. Psychol. 1999, 8, 155-163. [CrossRef]

50. Francois, P.L.; Cousin, E.; Blet, J.; Verger, P.; Argaud, D. Adequacy of the diet outside the home for a cohort of young male soldiers in france. Int. J. Food Sci. Nutr. 1997, 48, 393-399. [CrossRef]

51. Frank, L.L.; McCarthy, M.S. Telehealth coaching: Impact on dietary and physical activity contributions to bone health during a military deployment. Mil. Med. 2016, 181 (Suppl. 5), 191-198. [CrossRef] [PubMed]

52. Friedl, K.E.; Klicka, M.V.; King, N.; Marchitelli, L.J.; Askew, E.W. Effects of reduced fat intake on serum lipids in healthy young men and women at the U.S. Military academy. Mil. Med. 1995, 160, 527-533. [CrossRef] [PubMed]

53. Gaffney-Stomberg, E.; Lutz, L.J.; Rood, J.C.; Cable, S.J.; Pasiakos, S.M.; Young, A.J.; McClung, J.P. Calcium and vitamin $\mathrm{d}$ supplementation maintains parathyroid hormone and improves bone density during initial military training: A randomized, double-blind, placebo controlled trial. Bone 2014, 68, 46-56. [CrossRef] [PubMed] 
54. Gambera, C.P.J.; Schneeman, B.O.; Davis, P.A. Use of the food guide pyramid and us dietary guidelines to improve dietary intake and reduce cardiovascular risk in active-duty air force members. J. Am. Diet. Assoc. 1995, 95, 1268-1273. [CrossRef]

55. Hart, S.; Morrison, C. Effect of age, family status, and physical activity on selected dietary components of tac pilots. Mil. Med. 1992, 157, 397-401. [CrossRef]

56. Herzman-Harari, S.; Constantini, N.; Mann, G.; Lencovsky, Z.; Stark, A.H. Nutrition knowledge, attitudes, and behaviors of israeli female combat recruits participating in a nutrition education program. Mil. Med. 2013, 178, 517-522. [CrossRef]

57. Ismail, M.N.; Isa, M.; Janudin, A. Energy requirements of malaysian soldiers in a base camp. Malays 1996, 2, 168-174.

58. Jackson, R.T.; Sauberlich, H.E.; Skala, J.H.; Kretsch, M.J.; Nelson, R.A. Comparison of hemoglobin values in black and white male u.S. Military personnel. J. Nutr. 1983, 113, 165-171. [CrossRef]

59. King, N.; Fridlund, K.E.; Askew, E.W. Nutrition issues of military women. J. Am. Coll. Nutr. 1993, 12, 344-348. [CrossRef]

60. Klicka, M.V.; King, N.; Lavin, P.T.; Askew, E.W. Assessment of dietary intakes of cadets at the us military academy at west point. J. Am. Coll. Nutr. 1996, 15, 273-282. [CrossRef] [PubMed]

61. Kono, S.; Shinchi, K.; Wakabayashi, K.; Honjo, S.; Todoroki, I.; Sakurai, Y.; Imanishi, K.; Nishikawa, H.; Ogawa, S.; Katsurada, M. Relation of green tea consumption to serum lipids and lipoproteins in japanese men. J. Epidemiol. 1996, 6, 128-133. [CrossRef] [PubMed]

62. Lutz, L.J.; Gaffney-Stomberg, E.; Scisco, J.L.; Cable, S.J.; Karl, J.P.; Young, A.J.; McClung, J.P. Assessment of dietary intake using the healthy eating index during military training. US Army Med. Dep. J. 2013, Oct-Dec, 91-97.

63. Lutz, L.J.; Gaffney-Stomberg, E.; Williams, K.W.; McGraw, S.M.; Niro, P.J.; Karl, J.P.; Cable, S.J.; Cropper, T.L.; McClung, J.P. Adherence to the dietary guidelines for americans is associated with psychological resilience in young adults: A cross-sectional study. J. Acad. Nutr. Diet. 2017, 117, 396-403. [CrossRef] [PubMed]

64. Lutz, L.J.; Nakayama, A.T.; Karl, J.P.; McClung, J.P.; Gaffney-Stomberg, E. Serum and erythrocyte biomarkers of nutrient status correlate with short-term a-carotene, b-carotene, folate, and vegetable intakes estimated by food frequency questionnaires in military recruits. J. Am. Coll. Nutr. 2019, 38, 171-178. [CrossRef] [PubMed]

65. Mathew, A.; Peters, U.; Chatterjee, N.; Kulldorff, M.; Sinha, R. Fat, fiber, fruits, vegetables, and risk of colorectal adenomas. Int. J. Cancer 2004, 108, 287-292. [CrossRef]

66. McAdam, J.; McGinnis, K.; Ory, R.; Young, K.; Fruge, A.D.; Roberts, M.; Sefton, J. Estimation of energy balance and training volume during army initial entry training. JISSN 2018, 15. [CrossRef]

67. McClung, H.L.; Champagne, C.M.; Allen, H.R.; McGrawc, S.M.; Youngc, A.J.; Montainc, S.J.; Crombied, A.P. Digital food photography technology improves efficiency and feasibility of dietary intake assessments in large populations eating ad libitum in collective dining facilities. Appetite 2017, 116, 389-394. [CrossRef]

68. Milne, D.B.; Schnakenberg, D.D.; Johnson, H.L.; Kuhl, G.L. Trace mineral intake of enlisted military personnel. Preliminary observations. J. Am. Diet. Assoc. 1980, 76, 41-45.

69. Mullie, P.; Aerenhouts, D.; Clarys, P. Demographic, socioeconomic and nutritional determinants of daily versus non-daily sugar-sweetened and artificially sweetened beverage consumption. Eur. J. Clin. Nutr. 2012, 66, 150-155. [CrossRef]

70. Mullie, P.; Clarys, P. Beer, wine and lifestyle: A cross-sectional study of the belgian military population. Mil. Med. 2015, 2, 33. [CrossRef] [PubMed]

71. Mullie, P.; Clarys, P.; Hulens, M.; Vansant, G. Reproducibility and validity of a semiquantitative food frequency questionnaire among military men. Mil. Med. 2009, 174, 852-856. [CrossRef] [PubMed]

72. Mullie, P.; Godderis, L.; Clarys, P.; Mullie, P.; Godderis, L.; Clarys, P. Determinants and nutritional implications associated with low-fat food consumption. Appetite 2012, 58, 34-38. [CrossRef] [PubMed]

73. Mullie, P.; Guelinckx, I.; Clarys, P.; Degrave, E.; Hulens, M.; Vansant, G. Cultural, socioeconomic and nutritional determinants of functional food consumption patterns. Eur. J. Clin. Nutr. 2009, 63, 1290-1296. [CrossRef] [PubMed]

74. Nakayama, A.T.; Lutz, L.J.; Hruby, A.; Karl, J.P.; McClung, J.P.; Gaffney-Stomberg, E. A dietary pattern rich in calcium, potassium, and protein is associated with tibia bone mineral content and strength in young adults entering military training. Am. J. Clin. Nutr. 2019, 109, 186-196. [CrossRef] 
75. Nkondjock, A.; Bizome, E. Dietary patterns associated with hypertension prevalence in the cameroon defence forces. Eur. J. Clin. Nutr. 2010, 64, 1014-1021. [CrossRef]

76. Rahmani, J.; Milajerdi, A.; Dorosty-Motlagh, A. Association of the alternative healthy eating index (ahei-2010) with depression, stress and anxiety among iranian military personnel. J. R. Army Med. Corps 2017, 164, 87-91. [CrossRef]

77. Royer, S.D.; Thomas, D.T.; Winters, J.D.; Abt, J.P.; Best, S.; Poploski, K.M.; Zalaiskalnst, A.; Lephart, S.M. Physical, physiological, and dietary comparisons between marine corps forces special operations command critical skills operators and enablers. Mil. Med. 2018, 183, e341-e347. [CrossRef]

78. Shams-White, M.M.; Chui, K.; Deuster, P.A.; McKeown, N.M.; Must, A. Investigating items to improve the validity of the five-item healthy eating score compared with the 2015 health eating index in a military population. Nutrients 2019, 11, 251. [CrossRef]

79. Singh, A.; Deuster, P.A.; Day, B.A.; Smith, D.J.; De Bolt, J.E.; Doubt, T.J. Nutritional status of land-based u.S. Navy divers. Undersea Biomed. Res. 1988, 15, 135-145.

80. Smoak, B.L.; Singh, A.; Day, B.A.; Norton, J.P.; Kyle, S.B.; Pepper, S.J.; Deuster, P.A. Changes in nutrient intakes of conditioned men during a 5-day period of increased physical activity and other stresses. Eur. J. Appl. Physiol. 1988, 58, 245-251. [CrossRef] [PubMed]

81. Stark, A.H.; Weis, N.; Chapnik, L.; Barenboim, E.; Reifen, R. Dietary intake of pilots in the israeli air force. Mil. Med. 2008, 173, 780-784. [CrossRef] [PubMed]

82. Tharion, W.J.; Baker-Fulco, C.J.; Bovill, M.E.; Montain, S.M.; DeLany, J.P.; Champagne, C.M.; Hoyt, R.W.; Lieberman, H.R. Adequacy of garrison feeding for special forces soldiers during training. Mil. Med. 2004, 169, 483-490. [CrossRef] [PubMed]

83. Trent, L.K.; Conway, T.L. Dietary factors related to physical fitness among navy shipboard men. Am. J. Health Promot. 1988, 3, 12-25. [CrossRef] [PubMed]

84. Uglem, S.; Kjøllesdal, M.K.R.; Frølich, W.; Wandel, M. Effect of a nutrition intervention on intake of vegetables, fruits, and semi whole grain bread among low and high consumers in the norwegian national guard. Mil. Med. 2014, 179, 1013-1020. [CrossRef] [PubMed]

85. Uglem, S.; Stea, T.H.; Frolich, W.; Wandel, M. Body weight, weight perceptions and food intake patterns. A cross-sectional study among male recruits in the norwegian national guard. BMC Public Health 2011, 11, 343. [CrossRef] [PubMed]

86. Uglem, S.; Stea, T.H.; Kjollesdal, M.K.; Frolich, W.; Wandel, M. A nutrition intervention with a main focus on vegetables and bread consumption among young men in the norwegian national guard. Food Nutr. Res. 2013, 57. [CrossRef]

87. Versluis, E.E.; Groothof, G.; Laubscher, N.F.; Du Plessis, J.P. Results of a dietary survey of white men between the ages of eighteen and retirement. S. Afr. Med. J. 1973, 47, 1495-1497.

88. Williamson, D.A.; Martin, P.D.; Allen, H.R.; Most, M.M.; Alfonso, A.J.; Thomas, V.; Ryan, D.H. Changes in food intake and body weight associated with basic combat training. Mil. Med. 2002, 167, 248-253. [CrossRef]

89. Young, A.J.; Marriott, B.P.; Champagne, C.M.; Hawes, M.R.; Montain, S.J.; Johannsen, N.M.; Berry, K.; Hibbeln, J.R. Blood fatty acid changes in healthy young americans in response to a 10-week diet that increased n-3 and reduced n-6 fatty acid consumption: A randomised controlled trial. Br. J. Nutr. 2017, 117, 1257-1269. [CrossRef]

90. Balali-Mood, M.; Zilaee, M.; Ghayour-Mobarhan, M.; Sheikh-Andalibi, M.; Mohades-Ardalili, H.; Dehghani, H.; Ferns, G. Comparison of dietary macro and micro nutrient intake between iranian patients with long-term complications of sulphur mustard poisoning and healthy subjects. Malays. J. Med. Sci. 2014, $21,18-25$.

91. Barboriak, J.J.; Rooney, C.B.; Leitschuh, T.H.; Anderson, A.J. Alcohol and nutrient intake of elderly men. J. Am. Diet. Assoc. 1978, 72, 493-495. [PubMed]

92. Becerra, M.B.; Hassija, C.M.; Becerra, B.J. Food insecurity is associated with unhealthy dietary practices among us veterans in california. Public Health Nutr. 2016, 1-8. [CrossRef] [PubMed]

93. Chapman, K.M.; Ham, J.O.; Pearlman, R.A. Longitudinal assessment of the nutritional status of elderly veterans. J. Gerontol. A Biol. Sci. Med. Sci. 1996, 51, B261-B269. [CrossRef]

94. Ciubotaru, I.; Green, S.J.; Kukreja, S.; Barengolts, E. Significant differences in fecal microbiota are associated with various stages of glucose tolerance in african american male veterans. Transl. Res. 2015, 166, 401-411. [CrossRef] 
95. Gordon, S.R.; Kelley, S.L.; Sybyl, J.R.; Mill, M.; Kramer, A.; Jahnigen, D.W. Relationship in very elderly veterans of nutritional status, self-perceived chewing ability, dental status, and social isolation. J. Am. Geriatr. Soc. 1985, 33, 334-339. [CrossRef]

96. Hamirudin, A.H.; Walton, K.; Charlton, K.; Carrie, A.; Tapsell, L.; Milosavljevic, M.; Pang, G.; Potter, J. Feasibility of home-based dietetic intervention to improve the nutritional status of older adults post-hospital discharge. Nutr. Diet. 2017, 74, 217-223. [CrossRef]

97. Kaye, E.K.; Heaton, B.; Sohn, W.; Rich, S.E.; Spiro, A.; Garcia, R.I. The dietary approaches to stop hypertension (dash) diet and new and recurrent root caries events in men. J. Am. Geriatr. Soc. 2015, 63, 1812-1819. [CrossRef]

98. Koutrakis, N.E.; Goldstein, R.L.; Walia, P.; Polak, M.M.; Lazzari, A.A.; Tun, C.G.; Hart, J.E.; Garshick, E. Vitamin d, diet, and lifestyle in a chronic sci population. Spinal. Cord. 2019, 57, 117-127. [CrossRef]

99. Littman, A.J.; McFarland, L.V.; Thompson, M.L.; Bouldin, E.D.; Arterburn, D.E.; Majerczyk, B.R.; Boyko, E.J. Weight loss intention, dietary behaviors, and barriers to dietary change in veterans with lower extremity amputations. Disabil. Health J. 2015, 8, 325-335. [CrossRef]

100. Mehta, A.J.; Cassidy, A.; Litonjua, A.A.; Sparrow, D.; Vokonas, P.; Schwartz, J. Dietary anthocyanin intake and age-related decline in lung function: Longitudinal findings from the va normative aging study. Am. J. Clin Nutr 2016, 103, 542-550. [CrossRef] [PubMed]

101. Nosova, E.V.; Bartel, K.; Chong, K.C.; Alley, H.F.; Conte, M.S.; Owens, C.D.; Grenon, S.M. Analysis of nutritional habits and intake of polyunsaturated fatty acids in veterans with peripheral arterial disease. Vasc. Med. 2015, 20, 432-438. [CrossRef] [PubMed]

102. Seddon, J.M.; George, S.; Rosner, B. Cigarette smoking, fish consumption, omega-3 fatty acid intake, and associations with age-related macular degeneration: The US twin study of age-related macular degeneration. Arch. Ophthalmol. 2006, 124, 995-1001. [CrossRef] [PubMed]

103. Shahnazari, M.; Ceresa, C.; Foley, S.; Fong, A.; Zidaru, E.; Moody, S. Nutrition-focused wellness coaching promotes a reduction in body weight in overweight us veterans. J. Acad. Nutr. Diet. 2013, 113, 928-935. [CrossRef] [PubMed]

104. Vidal, A.C.; Williams, C.D.; Allott, E.H.; Howard, L.E.; Grant, D.J.; McPhail, M.; Sourbeer, K.N.; Hwa, L.P.; Boffetta, P.; Hoyo, C.; et al. Carbohydrate intake, glycemic index and prostate cancer risk. Prostate 2015, 75, 430-439. [CrossRef]

105. Wang, X.; Ding, N.; Tucker, K.L.; Weisskopf, M.G.; Sparrow, D.; Hu, H.; Park, S.K. A western diet pattern is associated with higher concentrations of blood and bone lead among middle-aged and elderly men. J. Nutr 2017, 7, 7. [CrossRef]

106. Young, J.B.; Troisi, R.J.; Weiss, S.T.; Parker, D.R.; Sparrow, D.; Landsberg, L. Relationship of catecholamine excretion to body size, obesity, and nutrient intake in middle-aged and elderly men. Am. J. Clin. Nutr. 1992, 56, 827-834. [CrossRef]

107. Hise, M.E.; Sullivan, D.K.; Jacobsen, D.J.; Johnson, S.L.; Donnelly, J.E. Validation of energy intake measurements determined from observer-recorded food records and recall methods compared with the doubly labeled water method in overweight and obese individuals. Am. J. Clin. Nutr. 2002, 75, 263-267. [CrossRef]

108. Thompson, F.E.; Subar, A.F. Dietary Assessment Methodology, 4th ed.; Elsevier Science: San Diego, CA, USA, 2017.

109. Hill, N.; Fallowfield, J.; Price, S.; Wilson, D. Military nutrition: Maintaining health and rebuilding injured tissue. Philos. Trans. R. Soc. Lond. B Biol. Sci. 2011, 366, 231-240. [CrossRef]

110. Cade, J.E.; Burley, V.J.; Warm, D.L.; Thompson, R.L.; Margetts, B.M. Food-frequency questionnaires: A review of their design, validation and utilisation. Nutr. Res. Rev. 2004, 17, 5-22. [CrossRef]

111. Jackson, K.A.; Byrne, N.M.; Magarey, A.M.; Hills, A.P. Minimizing random error in dietary intakes assessed by 24-h recall, in overweight and obese adults. Eur. J. Clin. Nutr. 2007, 62, 537-543. [CrossRef] [PubMed]

112. Holmes, B.; Dick, K.; Nelson, M. A comparison of four dietary assessment methods in materially deprived households in england. Public Health Nutr. 2008, 11, 444-456. [CrossRef] [PubMed]

113. Naska, A.; Lagiou, A.; Lagiou, P. Dietary assessment methods in epidemiological research: Current state of the art and future prospects. F1000Research 2017, 6. [CrossRef] [PubMed] 
114. Kirkpatrick, S.I.; Subar, A.F.; Douglass, D.; Zimmerman, T.P.; Thompson, F.E.; Kahle, L.L.; George, S.M.; Dodd, K.W.; Potischman, N. Performance of the automated self-administered 24-hour recall relative to a measure of true intakes and to an interviewer-administered 24-h recall. Am. J. Clin. Nutr. 2014, 100, 233-240. [CrossRef] [PubMed]

115. National Cancer Institute. Automated Self-Administered 24-Hour Dietary Assessment Tool. Secondary Automated Self-Administered 24-hour Dietary Assessment Tool. Available online: https://epi.grants.cancer. gov/asa24/ (accessed on 1 August 2019).

116. Schumm, J.A.; Chard, K.M. Alcohol and stress in the military. Alcohol Res. 2012, 34, 401-407. [PubMed]

117. US Department of Veterans Affairs. Veteran Population Projections 201; Affairs, D.V., Ed.; US Department of Veterans Affairs: Washington, DA, USA, 2016.

118. Australian Government. 2016-17 annual Report. Secondary 2016-2017 Annual Report. Available online: http://www.defence.gov.au/AnnualReports/16-17/Chapter7.asp (accessed on 24 August 2018).

119. Ministry of Defence. UK Armed Forces Quarterly Service Personnel Statistics; Ministry of Defence: London, UK, 2018. Available online: https://www.gov.uk/government/statistics/quarterly-service-personnel-statistics2018 (accessed on 16 August 2019).

120. The Army Australia. Army-Our People. Secondary Army-Our People. Available online: https://www.army. gov.au/our-people/corps?page=1 (accessed on 16 August 2019).

121. Almond, N.; Kahwati, L.; Kinsinger, L.; Porterfield, D. Prevalence of overweight and obesity among u.S. Military veterans. Mil. Med. 2008, 173, 544-549. [CrossRef]

122. Global Burden of Disease Collaborative Network. Global Burden of Disease Study 2017 (gbd 2017) Reference Life Table. Secondary Global Burden of Disease Study 2017 (gbd 2017) Reference Life Table. Available online: http://ghdx.healthdata.org/record/global-burden-disease-study-2017-gbd-2017-reference-life-table (accessed on 3 October 2019).

123. McLaughlin, R.; Wittert, G. The obesity epidemic: Implications for recruitment and retention of defence force personnel. Obes. Rev. 2009, 10, 693-699. [CrossRef]

124. Department of Defense. Population Representation in the Military Services; Office of the Under Secretary of Defense PaR, Ed.: Washington, DC, USA, 2017.

125. Deparment of Defense. Women in the Army. Secondary Women in the Army. Available online: https: //www.army.mil/women/index.html (accessed on 20 September 2019).

126. Australian Government. Landmark Moment for Women in the adf. Secondary Landmark Moment for Women in the adf. Available online: https://www.pmc.gov.au/news-centre/office-women/landmark-momentwomen-adf (accessed on 20 September 2019).

127. Goldzweig, C.L.; Balekian, M.P.H.; Rolon, C.; Yano, E.M.; Shekelle, P.G. The state of women veterans' health research. J. Gen. Intern. Med. 2006, 3, S82-S92. [CrossRef]

(C) 2020 by the authors. Licensee MDPI, Basel, Switzerland. This article is an open access article distributed under the terms and conditions of the Creative Commons Attribution (CC BY) license (http://creativecommons.org/licenses/by/4.0/). 